\title{
FOREIGN CAPITAL AND ECONOMIC DEVELOPMENT IN HUNGARY
}

\author{
V. SZEKERES \\ (Received: 26 October 2000; revision received: 4 January 2001; \\ accepted: 22 May 2001)
}

\begin{abstract}
In economics literature, a number of authors emphasize the need to study both domestic and foreign enterprises in order to properly grasp the effect of foreign direct investment on the local economy. Differences between foreign and domestic enterprises stem from the fact that multinational enterprises operate in a global network extending into many countries, which most certainly exerts influence on all aspects of their production activity. This paper presents a comparative analysis of performance of domestic and three types of foreign enterprises in Hungary. Total-factor productivity, factor intensity, wages, export intensity, profitability, as well as the effective rate of tax are examined by the combined tools of comparison, regression analysis and Wilcoxon test for data of the whole economy of Hungary. While foreign firms are found to contribute to the revitalization of the economy as far as capital intensity, productivity, export performance and level of wages are concerned, they do not yet seem to produce profitably.
\end{abstract}

Keywords: foreign direct investment, economic development, transition countries

JEL classification index: F21, O16, P27

\section{INTRODUCTION}

A great deal of interest is devoted to how foreign enterprises produce and how they perform in various respects in Hungary, yet the number of papers and evidence on these matters are still scanty, leaving demand for further investigation. ${ }^{1}$ In economics literature, a number of authors emphasized the need to study both domestic and foreign enterprises in order to properly grasp the effect of foreign direct investment on the local economy. This approach puts great emphasis on the

1 Foreign enterprises here indicate those firms, which have some foreign ownership in the par-value capital registered.

Correspondence: V. Szekeres, Tezukayama Gakuin University, Human Cultural Studies, 4-2-2 Harumidai, Sakai-shi, Osaka, Japan.E-mail: szekeres@hcs.tezuka-gu.ac.jp or valeria@tateyama.hu 
"domestic alternatives" of foreign firms. From the viewpoint of evaluating the impact of foreign firms on various parameters of development, the examination of the aspects that distinguish them from their local counterparts is important. Differences between foreign and domestic enterprises stem from the fact that multinational enterprises operate in a global network extending into many countries, which most certainly exerts influence on all aspects of their production activity. ${ }^{2}$

The eclectic theory of Dunning suggests that multinationals have ownership-specific advantages that allow them to produce and successfully compete with domestic producers in a host country, which enjoys certain advantages vis-à-vis them, as far as familiarity with the local legal or business culture is concerned. Dunning points out that these firm-specific advantages mainly include physical as well as intangible assets embodied in managerial capabilities, marketing or engineering. Advantages also arise from common governance, which are related partly to economies of scale on the firm level, partly to market power, technology accumulated worldwide and other attributes caused by multinationality. Operating in a number of countries stimulates the development of specific competencies, which are not available to purely national firms. ${ }^{3}$

This paper presents a comparative analysis of performance of domestic and three types of foreign enterprises in the Hungarian economy. We assume that the performance of foreign firms varies according to the size of the foreign share. We examine the total factor productivity, factor intensity, wages, export intensity, profitability, as well as the effective rate of tax.

Empirical research on the topic indicates that distinctive characteristics between domestic and foreign firms usually include all kinds of aspects of production, but the direction and extent of differences revealed greatly vary. Evidence is extensively found for the more intensive export activity of foreign firms, but the results of higher capital intensity, productivity and profitability are more diverse. Wages, however, are reported in almost all cases to exceed those paid at domestic firms, even with many variables controlled. ${ }^{4}$ The results of the research in this paper are more or less in line with these findings.

2 For references of empirical studies, see, for example, Kumar, N. (1990): Multinational Enterprises in India, London: Routledge, p. 49, or Newfarmer, R. S. and Marsh, L. C. (1981): Foreign Ownership, Market Structure and Industrial Performance: Brazil's Electrical Industry, Journal of Development Economics, 8: 47-75. Theoretical approach can be found at Dunning, J. H. (1993): Multinational Enterprises and the Global Economy, Addison-Wesley, pp. 263-267.

3 Dunning (1993), pp. 80-81.

4 For a review of empirical findings, see Caves, R. E. (1996): Multinational Enterprise and Economic Analysis, Cambridge: University Press, pp. 217-231. 
Methodology commonly used in empirical research includes discriminant and regression analysis, Wilcoxon tests, or simply comparisons of indicators for foreign and domestic firms. Research is often carried out for the economy as a whole, at the level of industries or on a firm-by-firm basis for a given size and product line. Here, we apply the combined tools of comparison, regression analysis and Wilcoxon test for indicators of firm groups in different ownership. The analysis is based on data of the whole economy of Hungary, making a distinction between 25 sectors.

The paper is divided as follows. Section 2 gives the production indicators investigated. In section 3 , we describe the firm groups and methodology applied in the paper. Section 4 presents a comparison of the productivity, factor intensity, wages, export activity, profitability, and the effective rate of tax of domestic and three types of foreign enterprises in Hungary. The results are compared to those of other authors. Section 5 deals with theoretical and policy implications and section 6 gives a conclusion. The Appendix includes the description of data.

\section{PRODUCTION INDICATORS UNDER ANALYSIS}

The scope of indicators in the analysis was chosen according to whether or not they reflect some contribution of foreign capital to parameters of economic development. Constraints of the data have made limitations to the choice. We examine the relative performance of foreign firms in respect of productivity, factor intensity, wages per labor, export, profitability, and rate of tax.

Total factor productivity is revealed in order to grasp the impact of foreign capital on the efficiency of the economy. In lack of unit labor cost indicators, we apply the number of employees in the model. We investigate factor intensity with the assumption that the equity/labor ratio shows somewhat of the level of technology at firm groups. Regrettably, we cannot eliminate the problem that the reported value of equity can largely be different according to which accounting methods are applied. Also, we cannot control the substitution between the capital and labor at different firm groups. Wages per labor is examined for the effect on demand and consumption. Exports are shown to investigate the competitiveness of firm groups as well as the degree to which they may help solve the balance-of-payments problem. Profitability and the effective rate of tax are also included in the analysis, because they may be considered as indicators of the potential contribution of firms to filling the budgetary gap. We have to take into account that intracompany pricing, supposed to be commonly in use at multinational enterprises, can distort values shown in profit statements. 


\section{DEFINITION OF FIRMS AND METHODOLOGY}

We make a distinction between three groups of foreign enterprises (FEs) according to the size of the share foreign investors hold of the nominal capital of a firm. FEs1 (Foreign enterprises 1) will include those firms at which the foreign share in nominal capital is below $25 \%$, but more than $0 \%$. FEs 2 will indicate enterprises where foreign share is between $25 \%$ and $50 \%$. Majority-foreign enterprises (FEs3) will refer to firms, in which the foreign share of nominal capital is above $50 \%$. Domestic enterprises (DEs) will include state-owned companies and private enterprises owned entirely by Hungarian nationals. In 1994, the number of firms was 170,240 , which increased remarkably to 227,064 by 1997 . FEs 3 accounted for 19,636 enterprises, while FEs2 only accounted for 4,502 and FEs1 for 1,583 companies in 1997.

In the empirical analysis total factor productivity assesses the economic and technical efficiency with which resources are converted into products at firms. It is usually expressed in terms of output per unit of total factor inputs in a function of quantities or prices of output and inputs, scale elasticity and output and input elasticity. Due to the necessary simplification of production and markets, TFP measures not only the "level of technology", but also the issues influencing production inside and outside the firm. By measuring only the inputs and output, the sole possibility is to treat engineering knowledge, plant organization or disruptions in market-affecting production process, as a whole. ${ }^{5}$ The Cobb-Douglas production function is applied in the analyses and specified as

$$
Q=A L^{a} K^{b}, \quad(A>0, a>0, b>0) .
$$

$Q, L$ and $K$ denote output, labor and capital input respectively. $A$ is a parameter representing the level of technology at time t. Parameters $a$ and $b$ are the output elasticity with regard to labor and capital respectively. The model is assumed to be linearly homogeneous $(a+b=1)$; in that case it has constant returns to scale, which means that if both inputs are multiplied by any positive constant, output changes by the same factor.

Regression equation of the Cobb-Douglas function is written as follows

$$
\ln \mathrm{Q}=\alpha+\mathrm{a} \ln \mathrm{L}+\mathrm{b} \ln \mathrm{K}, \quad(\alpha(\text { constant })=\ln \mathrm{A}) .
$$

5 Problems of TFP measurement are surveyed and discussed by Nishimizu, M., Robinson, S. (1984): Trade Policies and Productivity Change in Semi-Industrialized Countries, Journal of Development Economics, 16: 177-206. 
Models in the next section analyzing productivity at foreign and domestic firms in Hungary from various aspects take this equation as a base. The method of ordinary least squares is chosen to calculate regression.

Values of performance indicators for the four firm groups are displayed in box plots in Figures $1-5$ in section 4. The box plots are simple graphical representations of distribution by sectors of the indicators, showing the center and spread as well as unusually deviant data points, called outliers. To gain a better visualization of distribution in big enough figures, we omit outliers and shall only refer to them in the text. The horizontal line in the interior of the box indicates the center of distribution for the data, which is the so-called median. The height of the box is equal to the interquartile distance that is the difference between the third and first quartile of the data, indicating the spread or width of the distribution for the data. The whiskers, the dotted lines extending from the top and bottom of the box reach to the extreme values of the data or the 1.5 times height of the box from the center, whichever is less. The minimum and maximum values as well as the median and mean of the distribution by sectors of production indicators will also be referred to in the text. The figures are given for each category of enterprise for both years, after deflating the 1997 figures by an inflation rate of 1.87 to the 1994 basis.

We shall also refer to results of regression tests that examine whether or not the averages of indicators of firm groups significantly differ from each other. The method of ordinary least squared is applied to the calculations. The results of Wilcoxon signed-rank nonparametric tests are also introduced to explore whether the changes in production indicators between 1994 and 1997 are significant.

\section{RESULTS OF EMPIRICAL ANALYSIS}

\subsection{Total factor productivity}

Models are estimated with figures for the whole economy given by 25 sectors between 1994 and 1997. Since logarithm cannot be taken if figures are zero or negative, the database of each model is adequately adjusted to exclude those sectors, in which some of the figures cannot be interpreted. As with the results of TFP analyses for other countries, foreign firms are found more productive also in Hungary.

The first model is a cross-section model, analyzing the difference in the level of TFP at firms for every year between 1994 and 1997.

$$
\operatorname{lnVA}=\alpha+\beta_{1} \operatorname{lnL}+\beta_{2} \operatorname{lnEQ}+\beta_{3} \mathrm{DFE} 1+\beta_{4} \mathrm{DFE} 2+\beta_{5} \mathrm{DFE} 3
$$


Here, VA represents value added, $\alpha$ indicates the constant term, $\mathrm{L}$ is the number of employees, EQ denotes equity, and DFE1, DFE2 and DFE3 are dummies for FEs1, FEs2 and FEs3 respectively. The productivity level of DEs is expressed by the constant term a, and those of each foreign firm are represented by the sum of $\mathrm{a}$ and the corresponding coefficients of dummies. $\beta_{1}$ and $\beta_{2}$ indicate the degree of scale for the whole economy by years. This equation is estimated for each year.

Figures in Table 1 are the estimation results for model (1). They suggest that constant returns to scale might have existed in the economy during the four-year period, since $\left(\beta_{1}+\beta_{2}\right)$ was 1.08 in 1994, 0.99 in 1995 as well as in 1996, and 1.04 in 1997. ${ }^{6}$ The Cobb-Douglas production function with constant returns to scale seems to be a relevant model for the aggregate production in the Hungarian economy. Coefficients of the dummies for foreign firms show that they have substantially higher TFP. Among them, FEs2 and FEs1 amounted to the highest values in 1994, which were taken by FEs3 and FEs2 in the following two years. Fitness of the model is proven by the values of both F statistic and R squared. ${ }^{7}$

Table 1

Estimation results for equation (1)

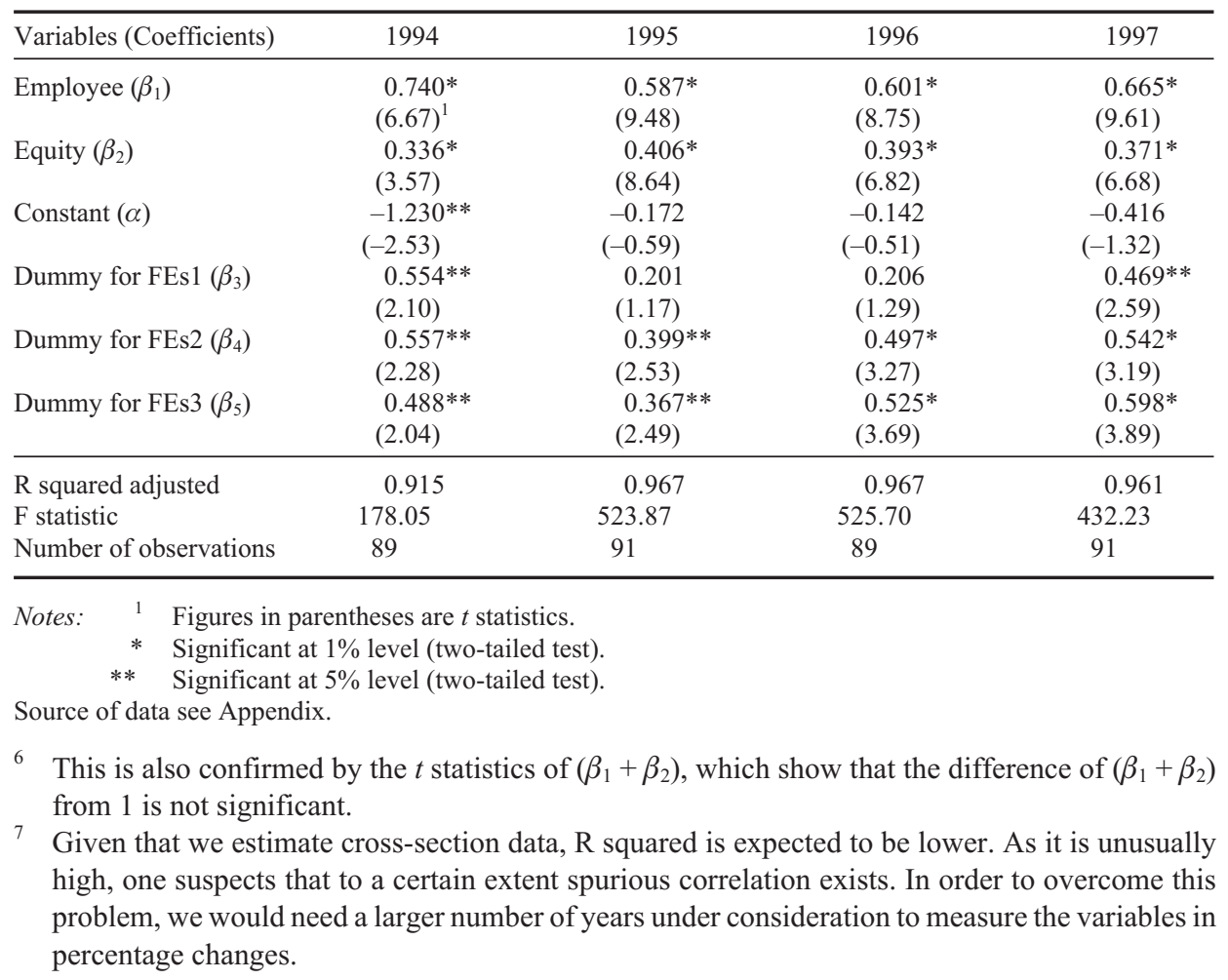

Acta Oeconomica 51 (2000/2001) 
The following model is the basic regression equation of the Cobb-Douglas production function, estimated for four categories of firms with 1997 data.

$$
\ln \mathrm{VA}=\alpha+\beta_{1} \operatorname{lnL}+\beta_{2} \operatorname{lnEQ}
$$

\section{Table 2}

Estimation results for equation (2)

\begin{tabular}{lcccc}
\hline Variables (Coefficients) & DEs & FEs1 & FEs2 & FEs3 \\
\hline Employee (b1) & $0.699^{*}$ & $0.608^{*}$ & $0.511^{*}$ & $0.560^{*}$ \\
& $(11.39)^{1}$ & $(5.05)$ & $(3.24)$ & $(3.16)$ \\
Equity (b2) & $0.312^{*}$ & $0.239^{* *}$ & $0.537^{*}$ & $0.552^{*}$ \\
& $(5.54)$ & $(2.87)$ & $(4.43)$ & $(3.60)$ \\
Constant (a) & -0.126 & $1.463^{*}$ & -0.171 & -0.764 \\
& $(-0.45)$ & $(3.29)$ & $(-0.41)$ & $(-1.46)$ \\
\hline R squared adjusted & 0.984 & 0.908 & 0.957 & 0.951 \\
F statistic & 727.75 & 99.88 & 243.95 & 216.36 \\
Number of observations & 24 & 21 & 23 & 23 \\
\hline
\end{tabular}

Notes: $\quad{ }^{1}$ Figures in parentheses are $t$ statistics.

* Significant at 1\% level (two-tailed test)

** Significant at 5\% level (two-tailed test).

Source of data see Appendix.

The most important finding that emerges from the examination of Table 2 is the increasing returns to scale at FEs3. On the contrary, FEs1 show decreasing returns to scale, while DEs seem to have rather constant scale. The $t$ statistics of $\left(\beta_{1}+\beta_{2}\right)$ for FEs 3 and FEs 1 also prove at a 5\% significance level that their returns to scale is different from unity. Due to the difference in the returns to scale, we cannot interpret the lower constant terms as indications of lower efficiency.

It may be claimed that there exists the problem of multicollinearity between equity and labor in both models above, although its possibility is low due to that the analysis was cross-section. In addition, the values of the correlation coefficients between equity and labor extend only from 0.48 to 0.81 .

Sun (1998) estimated the Cobb-Douglas production function for data of state-owned and foreign firms in Chinese industries in 1995. Using in a regression equation the figures of value added, net value of fixed capital used directly in production, and the number of employees on a yearly average, he found that the level of technology was higher at foreign enterprises. Agarwal (1979) calculated the total factor productivity in the Indian industries by the ratio of value added to the sum of capital and labor, given by the product of capital and opportunity cost, and 
labor and average wage rate, respectively. For the manufacturing average, TFP of foreign firms exceeded that of domestic ones by $55 \%{ }^{8}$

\subsection{Factor intensity}

We compare the relative use of the capital of foreign and domestic enterprises on Figure 1 that presents the main characteristics of the distribution of the factor intensity, obtained by dividing the equity figures by the corresponding number of labor in each sector, for each of the four groups of firms in Hungary in 1994 and 1997. The findings clearly serve as evidence towards the view that foreign enterprises are more capital-intensive, which is generally suggested by a number of researches carried out for other countries. Moreover, the finding here seems to be true for every industry, although a test of significance was possible only for the economy as a whole.

Figure 1 shows that foreign firms, largely in parallel with the increasing ratio of foreign participation, are more capital-intensive than domestic ones. The regression equation proves this for FEs3 in 1994 and for all foreign firms (with FEs 1 having the largest average value) in $1997 .{ }^{9}$ According to the median values, FEs 3 had the biggest amount of equity for an employee in 1997. FEs3 and FEs2 applied around a two times as capital-intensive production method as DEs.

From 1994 to 1997, the sizes of the boxes of FEs3, FEs2 and DEs diminished, which demonstrates that the capital intensity of these firm groups became characterized, in many sectors, by lower equity/labor ratios. The number of their outliers and large figures significantly decreased. The enlarged size of the boxes of FEs 1 in both years is owing to their substantial deviant values in some sectors, which were the electricity, gas, water, and real estate rent in 1997. The p-value of exact

8 Sun, H. (1998): Foreign Investment and Economic Development in China: 1979-96, Ashgate; Agarwal, J. P. (1979): Productivity of Foreign and Domestic Firms in Indian Industries, Weltwirtschaftliches Archiv, 115: 116-127.

9 The method of ordinary least squares is applied in calculating regressions. In the regression equations, the constant terms indicate the average indicator for domestic firms, and the coefficients of the dummies, together with the constant figures give the average values of foreign enterprises for a given year.

[Production indicator $]=\alpha \times$ constant $+\beta_{1} \times$ dummy $1+\beta_{2} \times$ dummy $2+\beta_{3} \times$ dummy 3

Dummy 1, 2 and 3 are equal to 1 if the data belong to firm type FE1, FE2 or FE3, respectively, and 0 otherwise. If the $t$ statistic of a dummy proves to be significant at least at a $10 \%$ level, it can be said that the indicators of foreign firms are significantly different from those of domestic ones. 
Wilcoxon signed-rank test reveals that the capital intensity significantly decreased at both DEs and FEs3 from 1994 until 1997. ${ }^{10}$

It is difficult to find an explanation for the decrease in capital intensity for all types of firms. Regrettably, it cannot be excluded that the consumer price index used as a deflator to the calculation of the 1997 figures made some distortion in the values.

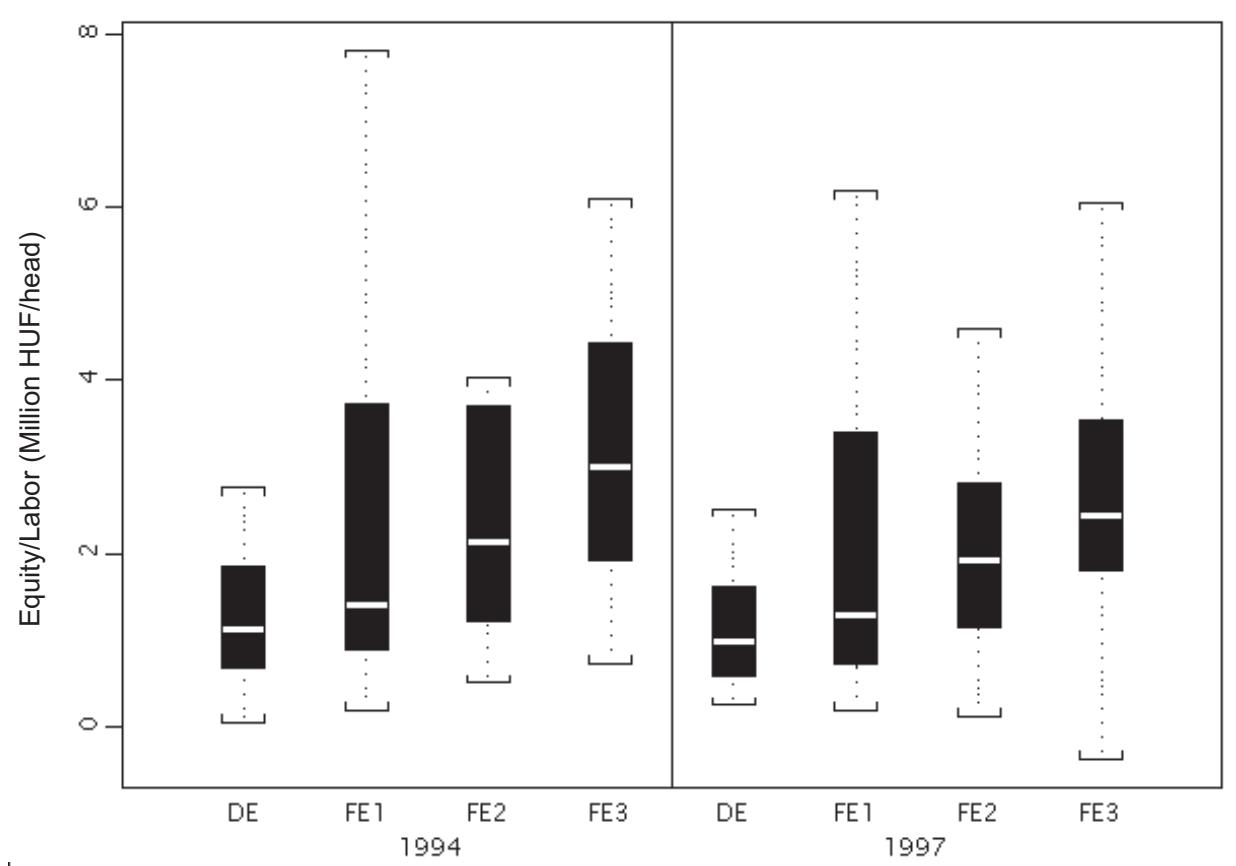

Figure 1. Equity/Labor

10 Wilcoxon test assumes that the figures of 1994 and 1997 compared have similar distribution. Showing the combined effect of the signs and ranking of the differences of each pair, it utilizes information on both the direction and the magnitude of the differences. In the Wilcoxon signed-rank test, signed (positive or negative) differences between two sets of matched samples are calculated by pairs, which are ranked by increasing absolute values from 1 to $\mathrm{N}$. There are $2^{N}$ possible orders of the signs, thus the probability of a given distribution is $2^{-N}$. The ranks belonging to one of the signs are summed up $(v)$. The probability $(P)$ of that the rank sum is equal to a given value $(\mathrm{V})$ can be gained by dividing the number of cases $\#(\mathrm{v} ; \mathrm{V})$ resulting the same rank sum by $2^{N} \mathrm{~N}$.

$$
2^{N} N \cdot P(V=v)=\#(v ; V) / 2^{N} P(V=v)=\# v ; V Y 2^{N} N
$$

The significance of the difference between two samples can be gained by adding up the probabilities of rank sums, which are at least or more extreme than that was calculated. Wilcoxon 
Jenkins (1991) surveyed the empirical literature on the impact of foreign firms in less developed countries with the finding that foreign firms tended to be more capital-intensive than local firms for manufacturing as a whole, but not in all individual industries. Particularly, in the case of matched pairs similar in terms of attributes other than ownership, there was no difference in capital intensity. According to Hunya (1997), fixed capital per employee was higher in firms with foreign capital than in domestic enterprises in Czech manufacturing. In his 1998 paper, the higher capital intensity of foreign firms was confirmed for Slovakia and Slovenia as well. However, Simoneti et al. (1998) found state companies to have an even higher equipment per employee indicator in Slovenia. Kirim (1986) examined the capital intensity of foreign and domestic firms in the Turkish pharmaceutical industry in 1983, but no difference was revealed after controlling for the scale of operations. Solomon and Forsyth (1977) found significant evidence for the much higher capital intensity of foreign firms in the Ghanaian manufacturing sector for 1970, even by using discriminant analysis controlled to give constant product composition of the two ownership groups. ${ }^{11}$

The relatively higher capital intensity of foreign enterprises may imply that this group of firms applies production methods of a higher technical level. It may also be indicated that foreign capital is primarily found in sectors and subsectors with a higher intensity of capital in production. For Hungary, a country with abundant labor, this may imply that FDI dynamically fosters the comparative advantages and does not make use of the static ones.

matched pairs test shows, through its p-values, whether the null hypothesis about no difference in the values of indicators can be rejected. If the null hypothesis is rejected, the alternative hypothesis proves to be true, which is given according to the positive or negative sign of the difference in the median values of the production indicators. Thus, for example, if the median value in 1997 is higher than in 1994, then the alternative hypothesis is that the difference in the indicators between the two years is greater than zero. The test made is a one-tailed test, because we seek to find out both the direction and the significance of differences in pairs.

11 Jenkins, R. (1991): The Impact of Foreign Investment on Less Developed Countries: Crosssection Analysis versus Industry Studies. In: Buckley, P. J. and Clegg, J. (eds): Multinational Enterprises in Less Developed Countries, London: MacMillan, pp. 111-130; Hunya (1997), ibid.; Simoneti, M., Rojec, M. and Rems, M. (1998): Enterprise Sector Restructuring and EU Accession of Slovenia, NATO-Economics Directorate, June 18-19, 1998, Ljubljana; Kirim, A. S. (1986): Transnational Corporations and Local Capital. Comparative Conduct and Performance in the Turkish Pharmaceutical Industry, World Development, 14 (4): 503-521; Solomon, R. F. and Forsyth, D. J. C. (1977): Substitution of Labor for Capital in the Foreign Sector: Some Further Evidence, Economic Journal, 87: 283-289. 


\subsection{Wages per labor}

Here we concern ourselves with the rate of wages paid to employees by firm categories. Regrettably, the lack of information on the skill composition of labor force does not make possible a more exact way of comparison. The research shows a much higher wage per labor for foreign firms, relative to domestic firms. This finding is the same as the general conclusion of other papers on the topic.

Figure 2 presents the characteristics of the distribution of the wages/labor ratios at the four firm groups in 1994 and 1997. As shown by every indicator of the distribution, foreign firms pay a remarkably higher salary to their employees than domestic enterprises. The regression test shows the difference to be significant for all foreign firm groups in both years. Foreign firms, among them particularly FEs3, are proved to pay considerably higher salaries than DEs. Foreign enterprise categories are also featured by substantially larger maximum figures, with FEs2 paying as large an amount as 1.31 million HUF per employee in mail and communications.

Between 1994 and 1997, the sums of wages per labor became slightly lower at all groups of enterprises, and the relative position of firms considerably changed.

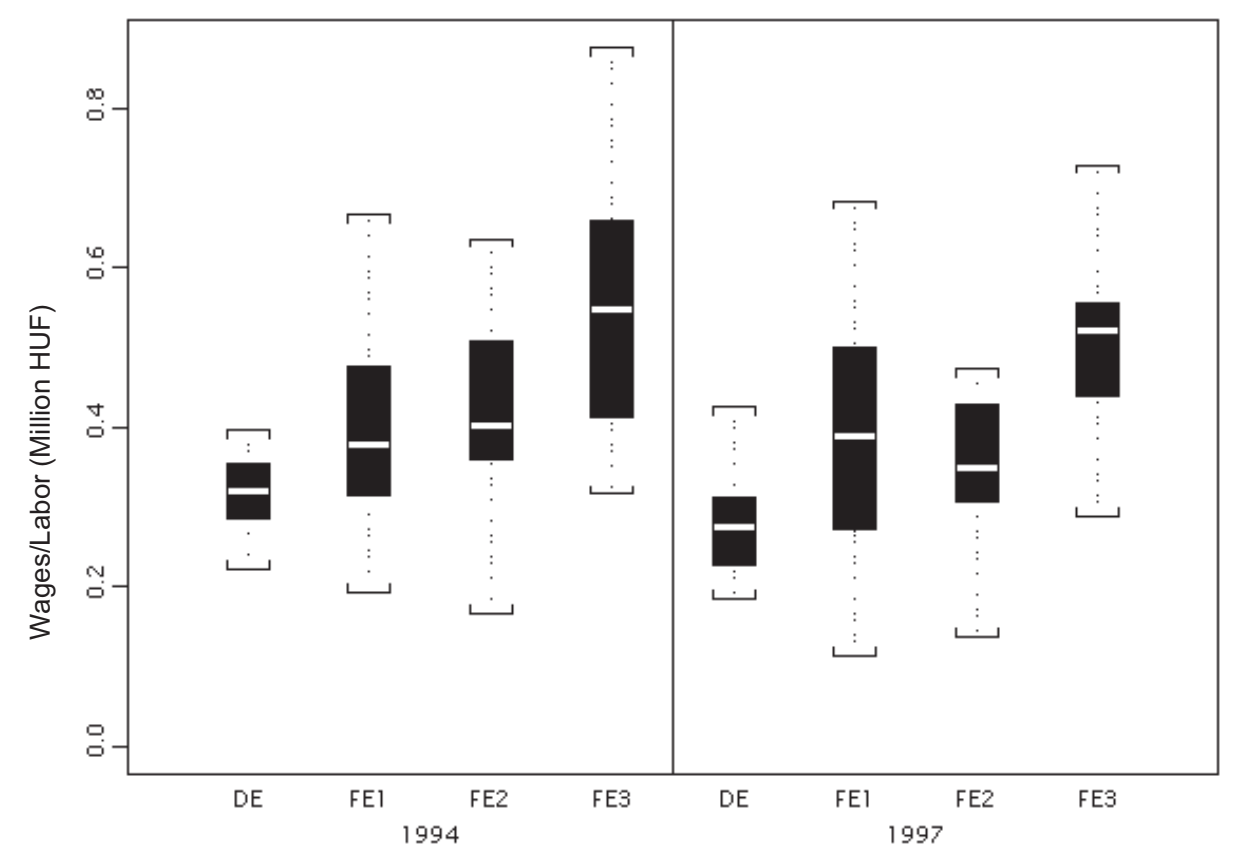

Figure 2. Wages/Labor 
The ratios, at least with respect to the median values, were proportionally decreasing from FEs3 towards DEs in 1994. Due, however, to an increase in the ratio of FEs1, unlike in those of other firms, the level of salaries at foreign firm groups became far from those at DEs by 1997. Wilcoxon test, however, confirms for all the firm groups that these amounts decreased in the four-year period.

The survey of Jenkins (1991) confirmed exclusively for less developed countries that wages paid to workers at MNEs were higher than those at local firms, although the difference may have reflected a different skill composition of the labor force. There were cases when no difference was indicated for any disaggregated types of labor or for unskilled labor. Hunya (1997) and Zemplinerova (1997) reported for the Czech economy for 1994 that average monthly wages in foreign-owned firms were almost $20 \%$ higher than the average of the companies surveyed. Similarly, Hunya (1998) found higher wages on average in manufacturing in Slovakia as well as in Slovenia. According to Aitken et al. (1996), however, there was no difference in wages between foreign and domestic firms after controlling for capital intensity and plant size or scale in the US in 1987. On the other hand, applying the same method for Mexico and Venezuela, found a considerably higher compensation ratio at foreign enterprises, particularly for skilled workers in Mexico, for the period of 1984-90 and 1977-89 respectively. Hill (1990) noted that papers on some Asian countries conclusively found foreign firms to pay higher salaries than local firms, even after controlling for their larger average size and distribution towards skill- and capital-intensive industries. ${ }^{12}$

Results of the analysis here and in other countries support the view that foreign firms tend to employ labor with relatively better skills than domestic enterprises do. This may reflect the presence of advanced technology at foreign firms. It may also be indicated that foreign firms are more able to pay higher wages, which is particularly true in the case of Hungary. Domestic enterprises in a poorer financial situation generally cannot offer wages high enough to attract the most educated part of the labor force. It must be added that unit labor cost indicators would have more precisely shown the difference.

12 Jenkins (1991) ibid.; Hunya, G. (1997): Foreign Direct Investment and its Effects in the Czech Republic, Hungary and Poland, WIIW Reprint-Series, No. 168, Vienna, June; Zemplinerova, A. (1997): The Role of Foreign Enterprises in the Privatization and Restructuring of the Czech Economy, WIIW Research Report, No. 238, Vienna, June; Hunya, G. (1998): Integration of CEEC Manufacturing into European Corporate Structures via Direct Investment, WIIW, Working Papers, Vienna, May; Aitken, B., Harrison, A. and Lipsey, R. E. (1996): Wage and Foreign Ownership. A Comparative Study of Mexico, Venezuela and the United States, Journal of International Economics, 40: 345-371; Hill, H. (1990): Foreign Investment and East Asian Economic Development, Asian-Pacific Economic Literature, 4 (2): 21-58. 


\subsection{Export activity}

This subsection investigates some details of export activity by revealing the features of the distribution of export/sales figures by sectors in 1994 and 1997. The findings are in a sharp contrast with those of most of the research carried out for other countries. Foreign companies, as compared to domestic ones, are clearly found here to export much larger quantities.

As presented on Figure 3, foreign firms account for remarkably higher relative export figures than domestic firm groups do. The difference was particularly large between DEs and FEs3 as well as DEs and FEs2, in 1997. In fact, regression analysis found it to be significant. FEs3 took huge values in machinery, light industry, furniture and metallurgy, with percentages of around $82 \%, 67 \%, 65 \%$ and $64 \%$ respectively. FEs 2 also appeared to actively export in light industry and machinery as well as in the transport industry. In 1997, export/sales values of FEs1 were rather similar to those of DEs, though in some sectors they were much higher. While FEs 1 amounted to about $57 \%$ as a maximum figure, DEs had only around $34 \%$, in the furniture and light industries respectively.

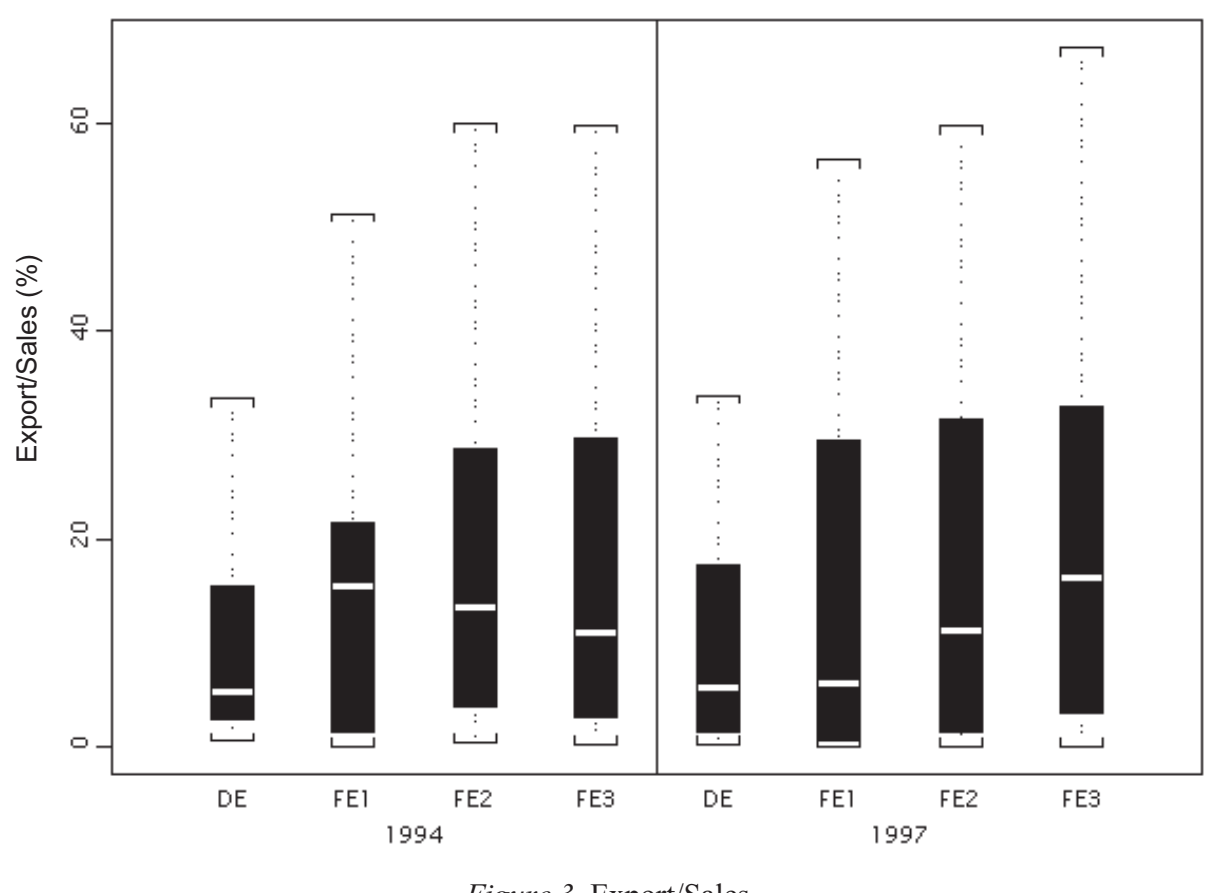

Figure 3. Export/Sales 
The direction of change in export intensity during the four-year period varied largely among the enterprise categories. While figures of DEs and FEs2 remained more or less stable, FEs1 accounted for considerably lower values in a number of sectors in 1997. On the contrary, FEs3 were featured by much stronger export intensity than three years before. The positions of the median values in the boxes that had enlarged at all types of firms by 1997, indicate a process towards higher export/sales values in sectors only for FEs3, whereas the contrary is true for the other firm categories. It may indicate that the production of a number of majority-foreign enterprises, established with the principal aim of export, became full scale by then. Exact Wilcoxon signed-rank test shows that export intensity significantly changed at FEs2 and FEs3, but with a negative sign at the former and a positive one at the latter.

According to a summary at Jenkins (1991), only six of the sixteen analyses found foreign firms more export-oriented than local ones, among which not more than merely two cases proved statistically significant. Hunya (1997) reported that exports represented $31 \%$ of sales in the case of all enterprises and $41 \%$ for foreign firms in the Czech manufacturing in 1994. Foreign firms were more export-oriented in Poland as well. This was also confirmed by 1996 data for Slovenia and by 1994 data for Slovakia at Hunya (1998). Export share in sales of foreign firms exceeded the average by around $20 \%$ and $10 \%$, respectively. Kumar and Siddharthan (1994) explained the export behavior of 406 Indian enterprises in a Tobit model of many exploratory factors for the 1987-88 to 1989-90 period, and found a positive impact of foreign ownership, which was, however, significant only in the non-electrical machinery of 13 industries. Lall and Mohammad (1983) also revealed that a foreign presence was positively associated with export propensities in 24 industries of India, though at a low level of statistical significance. ${ }^{13}$

Upon theoretical consideration, multinational firms are expected to extensively engage in export. The extent of their export activity relative to that of domestic firms may well be dependent, however, on other factors, such as their distribution among sectors or the competitiveness of local competitors. In Hungary, the much larger share of export in sales at foreign firms may also reflect the fact that during the privatization process, domestic enterprises with established and significant foreign markets became foreign-owned. It also has to be mentioned that the existence of tariff-free zones in Hungary, gives considerable explanation for the higher export intensity of foreign firms.

13 Jenkins (1991), ibid.; Hunya (1997), ibid., (1998), ibid.; Kumar, N. and Siddharthan, N. S. (1994): Technology, Firm Size and Export Behavior in Developing Countries: the Case of Indian Enterprises, Journal of Development Studies, 31: 289-309; Lall, S. and Mohammad, S. (1983-84): Foreign Ownership and Export Performance in the Large Corporate Sector of India, Journal of Development Studies, 20: 57-67. 


\subsection{Profitability}

In this subsection, we investigate the ratio of the net profit before tax to the sales of foreign and domestic firm categories for 1994 and 1997. The "not clearly better profitability" condition at foreign firms, shown as results of previous researches, is equally true in the present case, due partly to the recent presence of a large volume of foreign capital. Change in the indicators from 1994 to 1997 indicates, however, a considerable improvement.

According to Figure 4, foreign firm groups, relative to DEs, seem to have slightly higher profitability. However, regression analysis for average values reveals a significantly poorer profitability for FEs3 and FEs1 in 1994 and for FEs1 in 1997. The form of the box of FEs2, being longer towards the third quartile than below the median value, demonstrates the advantageous position of this group in many sectors in comparison with the others.

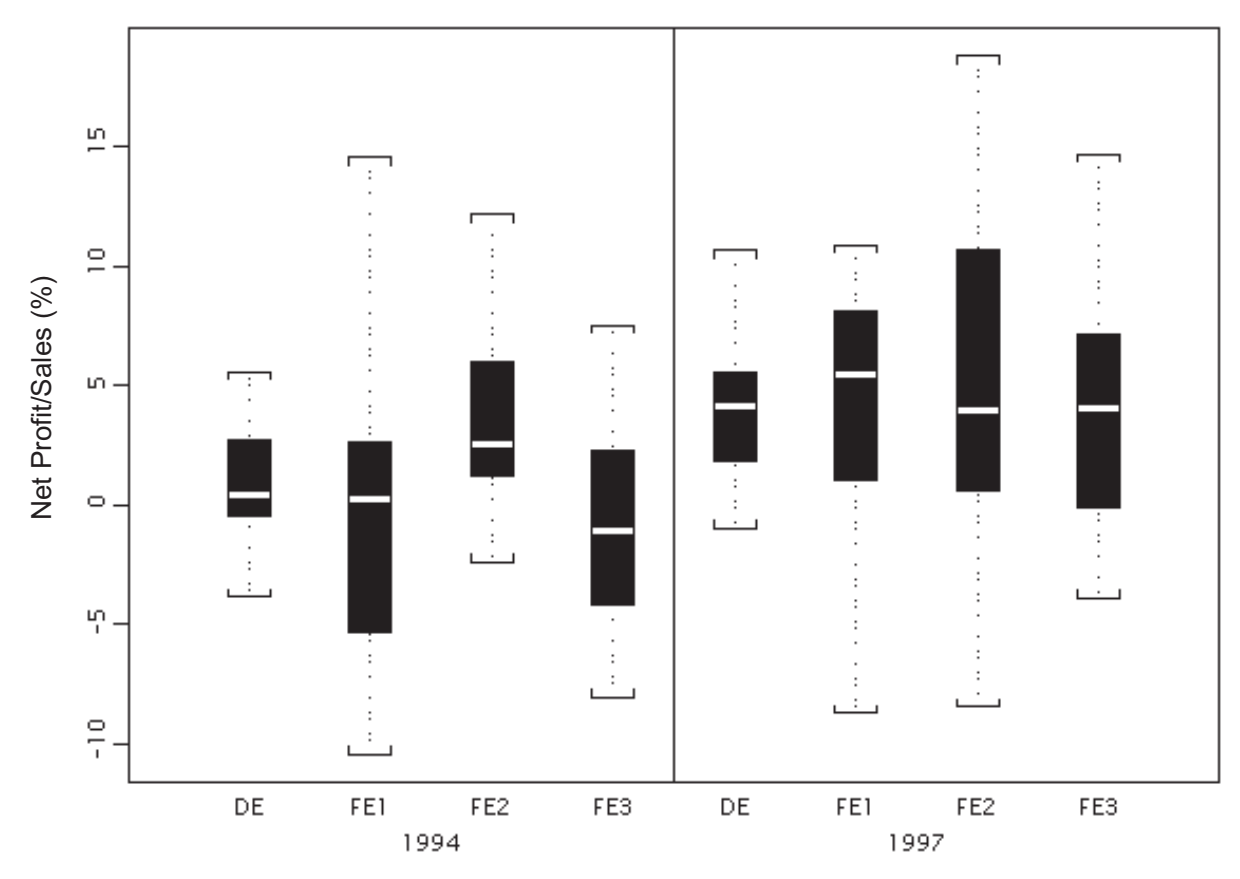

Figure 4. Net Profit/Sales

By 1997, a remarkable improvement occurred in almost all the indicators of the four firm groups. FEs 1 took a huge loss $(-52.6 \%)$ in mail and communications in 1994, but raised a positive return to sales by 1997 . They accumulated, however, a 
considerable amount of loss in the forestry $(-89.6 \%)$ and financial service. Considerable losses at FEs 3 in 1994 disappeared or largely decreased three years later, which may reflect an improving profitability situation after setting up production in Hungary at a number of firms of this category. The other two firm groups also showed higher values in 1997, but the huge profit of $144 \%$ of DEs in the financial service had substantially dropped by 1997. Performance of all the firm groups may have gained from the prosperity of the economy by 1997. In the exact Wilcoxon signed-rank test, the p-values are just above zero or 0.1 , which show a significantly improving financial situation for all the firm groups during the period under analysis.

Researches on the topic do not show clearly a superior performance for foreign enterprises relative to domestic ones. Simoneti et al. (1998) reported that foreign companies were behind private domestic ones in respect to net operating profit/loss in Slovenia in 1995. Discriminant analysis in the Indian manufacturing sector in 1980-81 by Kumar (1991) resulted in the finding that foreign firms enjoyed significantly higher profit margins than their local counterparts independently of their larger size. ${ }^{14}$

The "not clearly better profitability" of foreign firms is generally explained by their ability to manipulate prices among subsidiaries, which makes it possible to have a profit of a required amount. There are findings, which indicate that this is also true for Hungary. However, we may also find that foreign firms, with the recent establishment of the majority of their plants, are not yet able to attain profitable production. As was already mentioned above, we face the problem of measurement also here, in respect of profit and sales, which makes the result of comparison between firm groups less certain.

\subsection{Effective rate of tax}

The analysis below reveals the effective rate of tax of domestic and three categories of foreign firms for 1994 and 1997. As stated in the Appendix, in the effective rate of tax, the tax to be paid, consisting of calculated and complementary taxes reduced by tax allowances, is divided by the sum of the calculated, specific and complementary tax bases. The picture below may reflect that enterprises in different ownership have to a different extent taken advantage of the tax allowances and tax exemptions.

14 Simoneti et al. (1998) ibid.; Kumar, N. (1991): Mode of Rivalry and Comparative Behavior of Multinational and Local Enterprises. The Case of Indian Manufacturing, Journal of Development Economics, 35: 381-392. 
Figure 5 presents the characteristics of the distribution of the effective rate of firm groups. They reflect that FEs2 and FEs3 affect payments of tax in much less shares in their tax base than other firms do. This is confirmed by regression analysis for these foreign firms in both years. An examination of the extreme values reveals that all the foreign firm groups had just a few percentages in machinery in 1997, while FEs2 and FEs3 also had the same in mail, communications and the food industry, as well. Apart from these sectors, FEs3 also amounted to a very low ratio in the chemical industry. At the same time, all the firm groups amounted to a zero tax rate in fishing and repairing, while they had a maximum figure in the financial services.

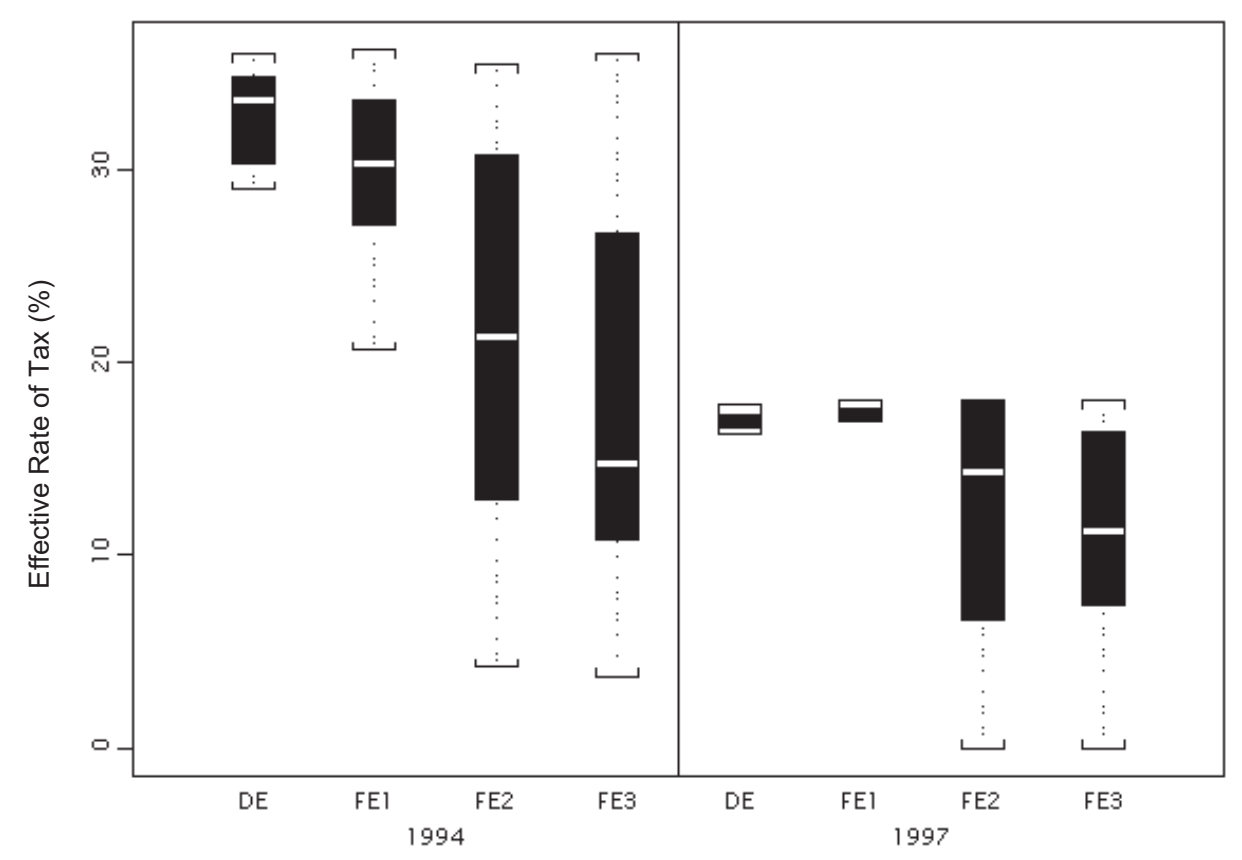

Figure 5. Effective Rate of Tax

A decrease in the effective tax rate at all firm groups by 1997 reflects the fact that the rate of corporate tax was diminished to half as of 1995. Enterprises with the highest and lowest median values in 1994, DEs and FEs3 respectively, paid $33.6 \%$ and $14.7 \%$ of the tax base. In 1997, the respective figures at FEs 1 and FEs 3 were $17.7 \%$ and $11.2 \%$. Exact Wilcoxon test reconfirms what became clear from the above, i.e. that all the enterprise groups paid tax at a lower rate in 1997 than in 1994. 
The big difference in the rate of tax of firm groups may reflect the result of the concession policy of the government towards foreign firms in Hungary. Those enterprises, which have invested capital of an amount large enough and contributed considerably to an increase in employment, are entitled to gain tax allowances of various forms. Foreign firms, having access to abundant capital, are more likely to make such a huge investment, and in fact seem more able to substantially decrease the sum of the taxes to be paid.

\section{THEORETICAL AND POLICY IMPLICATIONS}

According to the theory of Dunning, differences between foreign and domestic firms may mostly be determined by the distinctive features of multinational enterprises, which are considered to be the coordination of multiple value-adding activities across national boundaries, and internalizing cross-border markets for the intermediate products arising from these activities. This study has revealed that important difference of performance between foreign and domestic firms seems to be in productivity, factor intensity, wages and export activity in Hungary. Foreign firms as international networks of technological accumulation may have a more effective use of labor and capital, which may be reflected in higher wages. Enterprises locating themselves in more than one country can gain easier access to capital and, hence, face different input prices and possibly lower capital prices. Cross-border activity of production for markets in many countries may entail an increase in export.

Foreign enterprises transfer resources and capabilities between countries, which may be of vital importance with respect to the technological competence and the perspective of development in the host country. It is also decisive from the viewpoint of the host country, which kinds of inputs and methods of production are controlled by these firms. They may be different from those of domestic counterparts, due to their different product and market structure. Investment by foreign enterprises has been expected to ease the constraints of the lack of capital, to increase the competitiveness and to vitalize the sluggish economy in Hungary. In this paper we only have analyzed few aspects of the activity of firm groups, but the results suggest that foreign firms contribute to reaching these purposes. Particularly the higher level of productivity as well as the higher capital and export intensity, which altogether refers to better technology at foreign than at domestic firms, indicate that foreign firms have played an active role in the recovery of the economy in Hungary. Higher export intensity of foreign enterprises may also reflect a better ability to favorably affect the position of the country in the rank of international competitiveness. Through paying higher wages they not only boost de- 
mand, but also contribute more considerably to the income of government. However, the lower level of effective tax rate together with similar profitability implies that foreign firms do not yet pay amount of taxes proportionate to their weight in the economy. This may reflect that the government has made exemption to many foreign firms from paying various kinds of taxes.

\section{CONCLUSION}

In this paper, we have examined and compared various indicators of the production of domestic and three types of foreign enterprises in the economy of Hungary using 1994 through 1997 figures. The performance of foreign firms in Hungary is largely consistent with those suggested by the literature and observed in other countries. They operate under conditions substantially different from, and generally show production indicators significantly better than those of their domestic counterparts. The way of examination by making a distinction between various types of foreign firms according to the size of foreign ownership share is a rather unusual method of revealing differences from domestic enterprises. The research is intended to contribute greatly to the scarce literature of foreign direct investment in the transition countries.

FEs 3 and FEs2 are found to give the best performance in productivity. Capital intensity seems to be proportionally increasing with the increase in foreign ownership at firm groups. Foreign firms do not appear to perform clearly better than DEs with respect to profitability which improved at all firm groups during the four-year period. However, foreign enterprises (FEs3 in particular), are apparently featured by considerably more intensive export activity; an indicator that is really found to improve in parallel with the increase in the share of foreign ownership at firm groups for all the figures, in 1997. A clear-cut difference is also shown to be to the advantage of foreign firms in respect of wages per labor. DEs and FEs 1 evidently have a substantially higher rate of tax.

While foreign firms certainly contribute to the revitalization of the economy as far as capital intensity, productivity, export performance and level of wages are concerned, they may not yet provide a considerable contribution to the income of the government in the form of taxes and do not necessarily improve the current balance of the country. ${ }^{15}$ However, it may be argued that the large amounts of both tax allowance and imports are characteristics of only the beginning phase of the

15 Hunya, G. (1996): Foreign Direct Investment in Hungary: A Key Element of Economic Modernization, WIIW Research Reports, No. 226, Vienna, February, drew attention based on 1993 and 1994 figures that foreign firms tended to import more than they export. 
inflow of foreign direct investment, which become lower when the production of foreign firms and the concession policy of the government towards them become more established. Thus, the existence of foreign enterprises enhances the chance of an economic take-off in Hungary, if the microeconomic developments are not further hindered by macroeconomic constraints. A longer period of the economic activity of firms is needed to be able to make judgement on whether or not foreign investment will contribute to the relieving of these constraints and will continue to stimulate the firm sector in the future.

\section{APPENDIX: DATA AND MEASUREMENT}

Production figures are derived from the aggregate balance sheet data of all firms in Hungary, which were reported to the Tax and Financial Audit Office from 1994 to 1997. The figures used in the analysis include the output, sales, gross value added, exports, equity, number of employees, wages, net profit before tax and rate of tax by 25 sectors and the four firm groups mentioned in the text. The sectors are the following: agriculture, forestry, fishing, mining, food industry, tobacco industry, light industry, paper industry, chemical industry, non-metal products, metallurgy, machinery, furniture, electricity, gas and water, construction, sales, repairing, hotel and restaurant, transport, mail and communication, financial service, real estate and rent, education, health service, and other public services.

Sales constitute a considerable part of output sold on the market, and expressed as total net sales revenue. Conceivably, exports are a part of sales, sold abroad. Gross value added is defined as the total personal costs, excluding the sum of social security contribution, but including the rent of land. Equity includes nominal capital, capital reserves, retained earnings, accumulated losses and consolidated profit. Number of employees is given in a round figure of the annual average number of permanent staff. Net profit before tax implies the net operating profit, net profit on financial transactions and non-recurring receipts. In the effective rate of tax, the tax to be paid, consisting of calculated and complementary taxes reduced by tax allowances, is divided by the sum of the calculated, specific and complementary tax bases.

While most of the figures are available for firms with bookkeeping by both double and single entry, rate of tax is given only for firms with bookkeeping by double entry. In addition, these figures are missing for both types of enterprises in the sectors of fishing and repairing. 


\section{ACKNOWLEDGEMENT}

The author's thanks go to Professor Yuzo Hosoya (Department of Economics, Tohoku University, Sendai, Japan) and Professors Kazuo Yokokawa and Masao Satake (Department of International Economic Relations, Graduate School of International Cultural Studies, Tohoku University) for their valuable assistance and comments. Thanks are also due to Mr. Andrew John Barke and Mr. Zsolt Veresegyházy for technical assistance. 
